\title{
Nelson's Syndrome
}

\section{atualização}

\author{
ALIA MUNIR \\ JOHN NEWELL-PRICE
}

Academic Unit of Diabetes, Endocrinology \& Metabolism, School of Medicine and Biomedical Science, The University of Sheffield, Sheffield, UK.
Recebido em 30/07/07 Aceito em 08/08/07

\section{ABSTRACT}

Nelson's syndrome is a potentially severe complication of bilateral adrenalectomy performed in the treatment of Cushing's disease, and its management remains difficult. Of all of the features of Nelson's syndrome, the one that causes most concern is the development of a locally aggressive pituitary tumour, which, unusually for pituitary disease, may occasionally cause death from the tumour itself. This feature is especially pertinent given the increasing use in Cushing's disease of laparoscopic bilateral adrenal surgery as a highly effective treatment modality to control cortisol-excess. Despite numerous studies and reports, there is no formal consensus of what defines Nelson's syndrome. Thus, some will define Nelson's syndrome according to the classical description with an evolving pituitary mass after bilateral adrenalectomy, whereas others will rely on increasing plasma ACTH levels, even in the absence of a clear pituitary mass lesion on MRI. These factors need to be borne in mind when considering the reports of Nelson's syndrome, as there is great heterogeneity, and it is likely that overall the modern 'Nelson's syndrome' represents a different disease entity from that of the last century. In the present paper, clinical and epidemiological features of Nelson's syndrome, as well as its treatment modalities, are reviewed. (Arq Bras Endocrinol Metab 2007;51/8:1392-1396)

Keywords: Nelson's syndrome; Cushing's syndrome; Cortisol; ACTH; Dexamethasone; Adrenal; Pituitary; Tumour

\section{RESUMO}

\section{Síndrome de Nelson.}

A síndrome de Nelson (SN) é uma complicação potencialmente grave da adrenalectomia bilateral realizada para o tratamento da doença de Cushing e seu manejo permanece difícil. De todas as manifestações da $\mathrm{SN}$, aquela que causa maior preocupação é o desenvolvimento de um tumor hipofisário localmente agressivo, que pode (pouco usualmente para a doença hipofisária) ocasionalmente causar a morte pelo próprio tumor. Este achado é especialmente pertinente, dado o uso cada vez mais freqüente na doença de Cushing, da adrenalectomia bilateral por via laparoscópica, uma modalidade terapêutica altamente efetiva para o controle do excesso de cortisol. Apesar de numerosos estudos e publicações, não existe um consenso formal sobre a definição da SN. Assim, alguns irão definir a SN de acordo com a descrição clássica, como uma massa hipofisária que evolui após a adrenalectomia bilateral, enquanto outros irão se basear nos níveis crescentes dos níveis de ACTH plasmático, mesmo na ausência de uma lesão ou massa hipofisária nitidamente visível à RM. Esses fatores precisam ser relembrados quando se avaliam as publicações sobre $\mathrm{SN}$, na medida em que existe grande heterogeneidade, e é provável que no geral a "SN moderna" represente uma entidade patológica diferente daquela do século passado. Neste artigo, revisaremos achados clínicos e epidemiológicos da SN e também suas modalidades terapêuticas. (Arq Bras Endocrinol Metab 2007;51/8:1392-1396)

Descritores: Síndrome de Nelson; Síndrome de Cushing; Cortisol; ACTH; Dexametasona; Adrenal; Hipófise; Tumor 


\section{HISTORY AND DEFINITION}

$\mathrm{N}$ ELSON AND COLLEAGUES made the original description of a pituitary macroadenoma and high plasma ACTH, in a patient with Cushing's syndrome who had undergone bilateral adrenalectomy, in 1958 (1). Since that time there have been numerous similar case reports and series (2-8). Nelson's syndrome remains one of the major worries facing clinicians when considering managing patients with Cushing's disease by bilateral adrenalectomy. Of all of the features of Nelson's syndrome, the one that causes most concern is the development of a locally aggressive pituitary tumour, which, unusually for pituitary disease, may occasionally cause death from the tumour itself. This feature is especially pertinent given the increasing use in Cushing's disease of laparoscopic bilateral adrenal surgery as a highly effective treatment modality to control cortisol-excess $(9,10)$.

Despite numerous studies and reports, there is no formal consensus of what defines Nelson's syndrome. This is especially true in recent years since imaging with MRI allows precise documentation of any tumour progression, whereas historically patients presented with masses large enough to be found with CT, simple sella tomography, or with neuro-opthalmic complications (11). Moreover, widespread access to reliable plasma ACTH assays has greatly facilitated monitoring of patients. Thus, some will define Nelson's syndrome according to the classical description with an evolving pituitary mass, whereas others will rely on increasing plasma ACTH levels, even in the absence of a clear pituitary mass lesion on MRI (12). These factors need to be borne in mind when considering the reports of Nelson's syndrome, as there is great heterogeneity, and it is likely that overall the modern 'Nelson's syndrome' represents a different disease entity from that of the last century.

\section{INCIDENCE AND NATURAL HISTORY}

The reported incidence of Nelson's syndrome after bilateral adrenalectomy for Cushing's disease is 8-38\% (11). This wide variation in incidence is as likely to be due to differences in definition as much as bias of case mix in different centres. There is also great variation in the latency of onset from adrenalectomy to the diagnosis of Nelson's syndrome, ranging from a few months to 24 years, or more, emphasising the need for careful life-long follow-up $(10,11)$.

\section{PATHOPHYSIOLOGY}

Despite increased knowledge of the pathophysiology of corticotroph tumours, little is known of the pathology of the corticotroph tumours that progress to Nelson's syndrome (13). It is unclear whether the adrenalectomy and the lowering of the cortisol feedback at the pituitary itself stimulates tumour growth, or whether Nelson's syndrome develops in tumours that were programmed to behave in an aggressive fashion from the outset. Given that not all patients with Cushing's disease develop Nelson's syndrome following bilateral adrenalectomy, the reduced feedback from adrenal cortisol secretion cannot be the only factor, and indeed it is likely that the tumours that show progression with clinical consequence are a sub-set with an aggressive phenotype.

\section{CLINICAL FEATURES}

Patients may present with the physical and hormonal consequences of an expanding pituitary mass and, or, the effects of ACTH hyper-secretion. Mass effects include compression of the optic apparatus and visual field defects, headache, external ophthalmoplegias, and hypopituitarism (11). Deep cutaneous pigmentation is frequently present, and is due to ACTH stimulation of the melanocortin 1 receptors on melanocytes in the skin. Pigmentation is generalised, but may also occur in cutaneous scars and sites of abrasion, and in the buccal mucosa and tongue.

\section{PREDICTIVE FEATURES}

Given the concern over the onset of Nelson's syndrome after adrenalectomy, numerous studies have attempted to identify factors that predict its onset. The presence of tumour either at surgery or on imaging has been shown to predict onset, especially if there are aggressive characteristics or macroadenoma $(7,12)$. Young age at the time of adrenalectomy has been suggested to be predictive in some studies (14-17), but this is not a uniform finding in all (11). The duration of Cushing's disease is predictive in some series (18), but again not in all. One area that has attracted considerable interest is whether pituitary radiotherapy either diminishes the chance of developing Nelson's syndrome, or at least delays its onset: it has not been found to be of benefit in several series $(6,7,16)$, whereas other data suggest that prophylactic pituitary radio- 
therapy at the time of adrenalectomy reduces the risk of progression to Nelson's syndrome (12). Some of the difficulty in establishing the influence of these various factors is the heterogeneity of the series in question, not least of which because of the wide time-frame over which they have been variously reported, and the improvements in recent years in pituitary imaging.

More recently, some of these areas of controversy have been addressed by a modern, large and carefully reported series from Cochin Hospital, Paris, France (19). In this single centre series 53 patients treated by bilateral adrenalectomy for Cushing's disease were followed. All patients were assessed on follow up after adrenalectomy by clinical assessment, pituitary MRI and plasma ACTH. In contrast to other reports, any corticotroph tumour progression, as determined by pituitary MRI, was reported. The independent factors that predicted progression of corticotroph tumours included short duration of Cushing's disease and a high plasma ACTH, measured at $0800 \mathrm{~h}$, $20 \mathrm{~h}$ after the last dose of glucocorticoid. In the year following adrenalectomy an absolute increment of 100 $\mathrm{pg} / \mathrm{ml}(22 \mathrm{pmol} / \mathrm{l})$ was predictive of progression of the corticotroph tumour. Pituitary tumour on MRI at the time of adrenalectomy was also a factor predicting progression, but this was not an independent variable when these other two variables are taken into account. Interestingly, with a median follow up of 4.6 years (maximum follow up of 13.5 years) there was evidence of tumour progression on MRI in $50 \%$ of the patients followed, but in only one patient was there a complication related to the pituitary tumour itself: a shortlived oculomotor nerve palsy. These are important data as they indicate that whilst corticotroph tumour progression on MRI is common, the clinical consequence of this appears to be less worrisome than in some older series, at least with this duration of followup. An even longer-term follow up of these data are needed to give further reassurance.

\section{MONITORING}

Whilst the latency of onset from the time of bilateral adrenalectomy to pituitary tumour progression is usually within 3 years (19), progression may occur much later, and it is crucial to continue to carefully assess for tumour progression life-long. Whilst no formal guidelines can be set out, it is reasonable to perform pituitary MRI scans before adrenalectomy and then 6-12 months after adrenalectomy, and then yearly. As indicated above measurement of plasma ACTH is essential in monitoring. As indicated above this may be done by measurement of the $0800 \mathrm{~h}$ plasma ACTH, 20h after the last dose of glucocorticoid and before the morning dose of glucocorticoid, with an increment in the value compared to a previous value of $100 \mathrm{pg} / \mathrm{ml}$ being significant (19). A potential drawback of this type of monitoring is that high plasma ACTH levels are found in patients with primary adrenal insufficiency without pituitary pathology. In patients with Addison's disease plasma ACTH measured before morning glucocorticoid is frequently very elevated, but this suppresses rapidly 120 minutes after morning glucocorticoid $(20,21)$. In contrast, those with Nelson's syndrome fail to show incomplete suppression, and a cut-point of $200 \mathrm{pg} / \mathrm{ml}$ appears to be useful to define Nelson's syndrome (12). Thus, since the patient is attending for assessment anyway, measurement of plasma ACTH at $0800 \mathrm{~h}, 20 \mathrm{~h}$ after the last dose of glucocorticoid and before that morning's dose and then 120 minutes after the morning glucocorticoid may give more consistent results when monitoring for Nelson's syndrome: an increment in the pre-morning glucocorticoid plasma ACTH of $100 \mathrm{pg} / \mathrm{ml}$ compared to a previous measurement, or failure to suppress plasma ACTH to less than $200 \mathrm{pg} / \mathrm{ml} 2$ hours after morning glucocorticoid should prompt further assessment with imaging. Such an assessment can be performed, if needed, on a more frequent basis than pituitary MRI.

\section{Treatment}

\section{Observation}

If there is MRI evidence of limited tumour progression but with no anatomical compromise, observation and repeat imaging (3-6 months) is an acceptable strategy.

\section{Surgical}

Pituitary surgery may be performed for corticotroph tumour progression if the anatomy is favourable for such an approach $(22,23)$. Given that the risk is of further tumour expansion an attempt at complete hypophysectomy has been recommended, and is associated with a good long-term control of local tumour growth and lowering of plasma ACTH levels, but at a cost of increased hypopituitarism, including diabetes insipidus (22). Despite pituitary surgery some patients will have further progression alternative or adjuvant therapy is indicated $(22,23)$.

\section{Radiotherapy}

The use of fractionated external radiotherapy is well documented in the treatment of established Nelson's 
syndrome (24). Over time radiotherapy lowers plasma ACTH levels, but is associated with increases in longterm hypopituitarism. Whilst radiotherapy may control tumour growth in many instances, some tumours may continue to expand. More recently, large series treated by stereotactic radiotherapy, delivered by the gamma knife have been reported (25-27). In cases of a clear anatomical target this too is an effective modality of therapy, and may also be used after fractionated radiotherapy, as long as the dose to the optic apparatus can be kept within safe limits.

\section{Medical}

There has been a long interest in medical therapy to attempt to control plasma ACTH and tumour growth. Unfortunately, apart from isolated case reports there is no medical therapy that has been shown to consistently achieve these goals. Disappointing or variable results have been seen with sodium valproate (28-33), and currently licensed somatostatin analogues (34-37), although the multi-ligand analogue SOM230 (pasireotide) may prove of benefit (38). There are only occasional responses found with dopamine agonists such as cabergoline (39-42). Recent interest has focused on the use of PPAR gamma agonists in Nelson's syndrome. One report showed that two out of three patients responded to rosiglitazone with lowering of plasma ACTH levels, but one of these subsequently escaped (43). Rosiglitazone at maximum licensed doses has not been found to be effective (44). We have shown recently that even higher than licensed doses of rosiglitazone $(12 \mathrm{mg} /$ day $)$ are not effective in reducing plasma ACTH levels, and by inference tumour growth (45) (figure 1). The orally active alkylating agent temozolomide has been shown to be highly effective in a few aggressive pituitary tumours and in lowering prolactin and controlling tumour growth in highly aggressive prolactinomas (46-48). Although there are no reports of its use in Nelson's syndrome, temozolomide could be considered in patients with Nelson's syndrome not responding to other modalities of therapy. One major drawback of this agent is high cost.

\section{CONCLUSIONS}

Progression of corticotroph tumours, as detected by MRI, can be expected in up to half of patients undergoing bilateral adrenalectomy for Cushing's disease. Whilst this is a worrying statistic, and Nelson's syndrome should not be underestimated, with modern

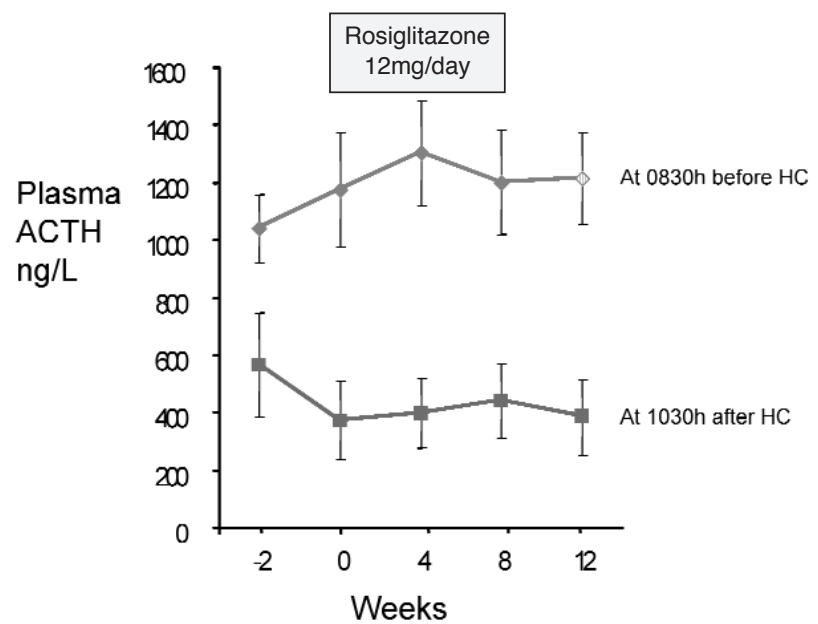

Figure 1. Plasma ACTH in Nelson's syndrome in response to high dose (12 $\mathrm{mg} /$ day) rosiglitazone (mean $\pm \mathrm{SEM}$ ): no significant changes in plasma ACTH are found.

follow-up including careful pituitary MRI and plasma ACTH, the actual numbers of patients that come to harm appears to be low. Thus, the risks associated with Nelson's syndrome need to be balanced against the risk of uncontrolled Cushing's disease, and in many cases may be acceptable. This is likely to be especially true if the duration of Cushing's syndrome is relatively long and no tumour is visible on pituitary MRI before adrenalectomy.

\section{REFERENCES}

1. Nelson DH, Meakin JW, Dealy JB Jr, Matson DD, Emerson K $\mathrm{Jr}$, Thorn GW. ACTH-producing tumor of the pituitary gland. N Engl J Med 1958;259:161-4.

2. Nelson DH, Meakin JW, Thorn GW. ACTH-producing pituitary tumors following adrenalectomy for Cushing's syndrome. Ann Intern Med 1960;52:560-9.

3. Kasperlik-Zaluska A, Hartwig W, Wislawski J, Guiot G. Nelson's syndrome following bilateral total adrenalectomy. Endokrynol Pol 1976;27:401-8.

4. Hopwood NJ, Kenny FM. Incidence of Nelson's syndrome after adrenalectomy for Cushing's disease in children: results of a nationwide survey. Am J Dis Child 1977;131:1353-6.

5. Barnett AH, Livesey JH, Friday K, Donald RA, Espiner EA. Comparison of preoperative and postoperative ACTH concentrations after bilateral adrenalectomy in Cushing's disease. Clin Endocrinol (Oxf) 1983;18:301-5.

6. McCance DR, Russell CF, Kennedy TL, Hadden DR, Kennedy L, Atkinson AB. Bilateral adrenalectomy: low mortality and morbidity in Cushing's disease. Clin Endocrinol (Oxf) 1993;39:315-21.

7. Pereira MA, Halpern A, Salgado LR, Mendonça BB, Nery M, Liberman B, et al. A study of patients with Nelson's syndrome. Clin Endocrinol (Oxf) 1998;49:533-9.

8. Kemink SA, Grotenhuis JA, De Vries J, Pieters GF, Hermus AR, Smals AG. Management of Nelson's syndrome: observations in fifteen patients. Clin Endocrinol (Oxf) 2001; 54:45-52. 
9. Thompson SK, Hayman AV, Ludlam WH, Deveney CW, Loriaux DL, Sheppard BC. Improved quality of life after bilateral laparoscopic adrenalectomy for Cushing's disease: a 10-year experience. Ann Surg 2007;245:790-4.

10. Newell-Price J, Bertagna X, Grossman AB, Nieman LK. Cushing's syndrome. Lancet 2006;367:1605-17.

11. Assie G, Bahurel H, Bertherat J, Kujas M, Legmann P, Bertagna X. The Nelson's syndrome. revisited. Pituitary 2004;7:209-15.

12. Jenkins PJ, Trainer PJ, Plowman PN, Shand WS, Grossman $A B$, Wass JA, et al. The long-term outcome after adrenalectomy and prophylactic pituitary radiotherapy in adrenocorticotropin-dependent Cushing's syndrome. J Clin Endocrinol Metab 1995;80:165-71.

13. Dahia PL, Grossman AB. The molecular pathogenesis of corticotroph tumors. Endocr Rev 1999;20:136-55.

14. Imai T, Funahashi $H$, Tanaka $Y$, Tobinaga J, Wada M, MoritaMatsuyama T, et al. Adrenalectomy for treatment of Cushing syndrome: results in 122 patients and long-term follow-up studies. World J Surg 1996;20:781-6; discussion 786-7.

15. Kemink L, Pieters G, Hermus A, Smals A, Kloppenborg P. Patient's age is a simple predictive factor for the development of Nelson's syndrome after total adrenalectomy for Cushing's disease. J Clin Endocrinol Metab 1994; 79:887-9.

16. Moore TJ, Dluhy RG, Williams GH, Cain JP. Nelson's syndrome: frequency, prognosis, and effect of prior pituitary irradiation. Ann Intern Med 1976;85:731-4.

17. Thomas CG Jr, Smith AT, Benson M, Griffith J. Nelson's syndrome after Cushing's disease in childhood: a continuing problem. Surgery 1984;96:1067-77.

18. Kelly WF, MacFarlane IA, Longson D, Davies D, Sutcliffe H. Cushing's disease treated by total adrenalectomy: long-term observations of 43 patients. Q J Med 1983;52:224-31.

19. Assie G, Bahurel H, Coste J, Silvera S, Kujas M, Dugue MA, et al. Corticotroph tumor progression after adrenalectomy in Cushing's Disease: A reappraisal of Nelson's Syndrome. J Clin Endocrinol Metab 2007;92:172-9.

20. Gilkes JJ, Rees LH, Besser GM. Plasma immunoreactive corticotrophin and lipotrophin in Cushing's syndrome and Addison's disease. Br Med J 1977;1:996-8.

21. Merza Z, Rostami-Hodjegan A, Memmott A, Doane A, Ibbotson V, Newell-Price J, et al. Circadian hydrocortisone infusions in patients with adrenal insufficiency and congenital adrenal hyperplasia. Clin Endocrinol (Oxf) 2006;65:45-50.

22. Kelly PA, Samandouras G, Grossman AB, Afshar F, Besser GM, Jenkins PJ. Neurosurgical treatment of Nelson's syndrome. J Clin Endocrinol Metab 2002;87:5465-9.

23. Ludecke DK, Breustedt HJ, Bramswig J, Kobberling J, Saeger W. Evaluation of surgically treated Nelson's syndrome. Acta Neurochir (Wien) 1982;65:3-13.

24. Howlett TA, Plowman PN, Wass JA, Rees LH, Jones AE, Besser GM. Megavoltage pituitary irradiation in the management of Cushing's disease and Nelson's syndrome: long-term follow-up. Clin Endocrinol (Oxf) 1989;31:309-23.

25. Mauermann WJ, Sheehan JP, Chernavvsky DR, Laws ER, Steiner L, Vance ML. Gamma Knife surgery for adrenocorticotropic hormone-producing pituitary adenomas after bilateral adrenalectomy. J Neurosurg 2007;106:988-93.

26. Wolffenbuttel BH, Kitz K, Beuls EM. Beneficial gamma-knife radiosurgery in a patient with Nelson's syndrome. Clin Neurol Neurosurg 1998;100:60-3.

27. Ganz JC, Backlund EO, Thorsen FA. The effects of Gamma Knife surgery of pituitary adenomas on tumor growth and endocrinopathies. Stereotact Funct Neurosurg 1993; 61(suppl 1):30-7.

28. Reincke M, Allolio B, Kaulen D, Jaursch-Hancke C, Winkelmann W. The effect of sodium valproate in Cushing's disease, Nelson's syndrome and Addison's disease. Klin Wochenschr 1988;66:686-9.

29. Loli P, Berselli ME, Frascatani F, Muratori F, Tagliaferri M. Lack of ACTH lowering effect of sodium valproate in patients with ACTH hypersecretion. J Endocrinol Invest 1984;7:93-6.
30. Gwinup G, Elias AN, Choi B. Failure of valproic acid to inhibit the growth of an ACTH-secreting pituitary adenoma. Acta Endocrinol (Copenh) 1984; 105:449-54.

31. Dornhorst A, Jenkins JS, Lamberts SW, Abraham RR, Wynn $V$, Beckford U, et al. The evaluation of sodium valproate in the treatment of Nelson's syndrome. J Clin Endocrinol Metab 1983; $56: 985-91$.

32. Ambrosi B, Bochicchio D, Riva E, Faglia G. Effects of sodium-valproate administration on plasma ACTH levels in patients with ACTH hypersecretion. J Endocrinol Invest 1983;6:305-6.

33. Elias AN, Gwinup G. Sodium valproate and Nelson's syndrome. Lancet 1981:2:252-3.

34. Kelestimur F, Utas C, Ozbakir O, Selcuklu A, Kandemir O, Ozcan N. The effects of octreotide in a patient with Nelson's syndrome. Postgrad Med J 1996;72:53-4.

35. Petrini L, Gasperi M, Pilosu R, Marcello A, Martino E. Longterm treatment of Nelson's syndrome by octreotide: a case report. J Endocrinol Invest 1994;17:135-9.

36. Lamberts SW, Uitterlinden P, Klijn JM. The effect of the longacting somatostatin analogue SMS 201-995 on ACTH secretion in Nelson's syndrome and Cushing's disease. Acta Endocrinol (Copenh) 1989;120:760-6.

37. Tyrrell JB, Lorenzi M, Gerich JE, Forsham PH. Inhibition by somatostatin of ACTH secretion in Nelson's syndrome. J Clin Endocrinol Metab 1975;40:1125-7.

38. van der Hoek J, Lamberts SW, Hofland LJ. The role of somatostatin analogs in Cushing's disease. Pituitary 2004;7:257-64.

39. Shraga-Slutzky I, Shimon I, Weinshtein R. Clinical and biochemical stabilization of Nelson's syndrome with long-term low-dose cabergoline treatment. Pituitary 2006;9:151-4.

40. Casulari LA, Naves LA, Mello PA, Pereira Neto A, Papadia C. Nelson's syndrome: complete remission with cabergoline but not with bromocriptine or cyproheptadine treatment. Horm Res 2004;62:300-5.

41. Pivonello R, Faggiano A, Di Salle F, Filippella M, Lombardi G, Colao A. Complete remission of Nelson's syndrome after 1year treatment with cabergoline. J Endocrinol Invest 1999;22:860-5.

42. Lamberts SW, Birkenhager JC. Bromocriptine in Nelson's syndrome and Cushing's disease. Lancet 1976;2:811.

43. Andreassen M, Kristensen LO. Rosiglitazone for prevention or adjuvant treatment of Nelson's syndrome after bilateral adrenalectomy. Eur J Endocrinol 2005;153:503-5.

44. Mullan KR, Leslie H, McCance DR, Sheridan B, Atkinson AB. The PPAR-gamma activator rosiglitazone fails to lower plasma ACTH levels in patients with Nelson's syndrome. Clin Endocrinol (Oxf) 2006;64:519-22.

45. Munir A, Song F, Ince P, Walters SJ, Ross R, Newell-Price J. Ineffectiveness of rosiglitazone therapy in Nelson's syndrome. J Clin Endocrinol Metab 2007:92:1758-63.

46. Lim S, Shahinian H, Maya MM, Yong W, Heaney AP. Temozolomide: a novel treatment for pituitary carcinoma. Lancet Oncol 2006;7:518-20.

47. Fadul CE, Kominsky AL, Meyer LP, Kingman LS, Kinlaw WB, Rhodes $\mathrm{CH}$, et al. Long-term response of pituitary carcinoma to temozolomide. Report of two cases. J Neurosurg 2006;105:621-6.

48. Neff LM, Weil M, Cole A, Hedges TR, Shucart W, Lawrence D, et al. Temozolomide in the treatment of an invasive prolactinoma resistant to dopamine agonists. Pituitary 2007;10:81-6.

\section{Address for correspondence:}

John Newell-Price

Senior Lecturer and Consultant Endocrinologist

Academic Unit of Diabetes, Endocrinology \& Metabolism

The University of Sheffield

Room OU142

O Floor

Royal Hallamshire Hospital

Glossop Road

Sheffield, S10 2JF, UK 